NBER WORKING PAPER SERIES

\title{
BLIND TIGERS AND RED-TAPE COCKTAILS: \\ LIQUOR CONTROL AND HOMICIDE IN LATE-NINETEENTH-CENTURY SOUTH CAROLINA
}

Howard Bodenhorn

Working Paper 22980

http://www.nber.org/papers/w22980

\author{
NATIONAL BUREAU OF ECONOMIC RESEARCH \\ 1050 Massachusetts Avenue \\ Cambridge, MA 02138 \\ December 2016
}

I thank Scott Barkowski, Cesar Castellon, Michael Makowsky, Chris Vickers, Eugene White, and seminar participants at the 2016 NBER Summer Institute and Rutgers University for comments. Clemson University's Creative Inquiry program for undergraduate research and the John E. Walker Department of Economics provided financial support. Gary Clary (SC Circuit Court Judge (ret.)) offered valuable insights into South Carolina criminal procedure. Mark Balon, James Cox, Michael Alan Diehl, Robert Doherty, William Galvin, and Camille Swanson provided valuable research assistance and fruitful discussions on the connection between prohibition and violence. The views expressed herein are those of the author and do not necessarily reflect the views of the National Bureau of Economic Research.

NBER working papers are circulated for discussion and comment purposes. They have not been peer-reviewed or been subject to the review by the NBER Board of Directors that accompanies official NBER publications.

(C) 2016 by Howard Bodenhorn. All rights reserved. Short sections of text, not to exceed two paragraphs, may be quoted without explicit permission provided that full credit, including () notice, is given to the source. 
Blind Tigers and Red-Tape Cocktails: Liquor Control and Homicide in Late-Nineteenth-Century South Carolina

Howard Bodenhorn

NBER Working Paper No. 22980

December 2016

JEL No. K14,K42,N41

\begin{abstract}
In 1893 South Carolina prohibited the private manufacture, transportation, and sale of alcohol and established a state monopoly in wholesale and retail alcohol distribution. The combination of a market decline in the availability of alcohol, reduced variety, and monopoly pricing at stateoperated outlets encouraged black markets in alcohol. Because black market participants tend to resort to extra-legal mechanisms for dispute resolution, including violence, one result of South Carolina's alcohol restriction was an increase in homicide. A continuous-treatment difference-indifference approach reveals that homicide rates increased by about 30 to 60 percent in counties that more vigorously enforced the law.
\end{abstract}

\author{
Howard Bodenhorn \\ John E. Walker Department of Economics \\ College of Business and Behavioral Science \\ 201-B Sirrine Hall \\ Clemson University \\ Clemson, SC 29634 \\ and NBER \\ bodenhorn@gmail.com
}




\section{Introduction}

Nineteenth-century Americans imbibed freely. Contemporary temperance organizations, such as the Anti-Saloon League, highlighted its extent and excesses. In 1890, 63 million Americans consumed 87 million gallons of distilled liquor, 29 million gallons of wine, and 856 million gallons of malt beverages, or the equivalent of 1.4 gallons of pure alcohol per person (Copeland 1892). What troubled temperance advocates more than the amount consumed was where it was consumed. Middle-class Americans were troubled by the increasingly ready availability of alcohol at saloons, where drinking, gambling, whoring, and brawling were virtually de rigueur (Timberlake 1966). Nationally, there were 2.2 saloons per thousand people and a total of 3.3 per thousand licensed sellers, which included saloons, liquor stores, and apothecary shops. Temperance proponents contended that the ready availability of alcohol produced "not only pauperism, crime and insanity, but also death, divorces and bad government" (Sheen 1910, p. 129). Government was complicit in the drinking problem because of the revenues raised at all levels of government through excise taxes and license fees. Prohibitionists argued that government would be better served by cutting its cord to alcohol because it spent more in prosecuting and punishing alcohol-induced crime than it took in through alcohol taxes and fees.

There is little doubt that crime and alcohol were related. Carroll D. Wright, director of the Massachusetts Bureau of Labor Statistics, found for Boston in 1880 that 72 percent of all magistrate court convictions were for public drunkenness and illegal or unlicensed vending. Of the other crimes, which ranged in seriousness from adultery up to aggravated assault, Wright found that $45.5 \%$ were committed under the influence and $28.6 \%$ were committed by known drunkards and others with a history of drinking problems. Prohibition and strict regulations on alcohol found broad public support because people believed that alcohol fueled violence and other bad behaviors.

But Miron (1999, 2004) and O’Flaherty and Sethi (2010) contend that prohibitions can have a countervailing effect on violence. Prohibition or any binding restriction on highly desired goods encourages the emergence of black markets. 
Black markets tend to generate turf wars, which are extralegal attempts to create local geographic monopolies, and substantial cash holdings, which encourages robbery, especially armed robbery (Miron and Zweibel 1995; Burrus 1999). Black markets, like other markets, also generate commercial and contractual disputes that give rise to resolution mechanisms. Absent the usual dispute resolution mechanisms available to participants in legal markets (negotiation, lawsuits, and arbitration) and the usual dispute resolution institutions (courts and government agencies), participants in underground markets resolve disputes through violence. Courts will not enforce agreements involving the manufacture, transportation, and distribution of prohibited or tightly regulated goods, and participants have no access to these institutions without incriminating themselves. Black market participants then rely on guns rather than lawyers to resolve commercial and contractual disputes. As Clarence Darrow observed when asked about the 215 liquor-related killings in a three-year period in Prohibition-era Chicago, broken contracts in markets for prohibited goods do not "lend themselves to polite resolution" (Okrent 2010, p. 275) At the limit, a combination of drug prohibition and ineffective law enforcement can generate "war zones," in which fears of violence fuel preemptive violence (O'Flaherty and Sethi 2010).

Theoretical modeling, however, generates ambiguous predictions concerning the connection between prohibitions, enforcement activities, and violence. Burrus (1999) models illegal drug distribution as Cournot competition between dealers who use violence to secure geographic markets. One implication is that intensified law enforcement efforts reduce the profits from territorial monopolies, which reduces the marginal benefit of violence. A second implication, however, is that if demand for the prohibited good increases, turf war violence intensifies in the short term. Burrus's (1999) second implication is relevant in the South Carolina experience. Like other states along the southern Appalachians, South Carolina had a long-standing culture of moonshining, or the distillation of inexpensive, small batches of corn whiskey sold informally to avoid federal taxation (Busemann 2002). The establishment of the dispensary system likely increased the demand for moonshine, 
which may have perturbed a low-violence equilibrium among established producers by encouraging entry. Entry then elicited a short-term increase in violence as new and established producers battled over market share.

Flores (2016) also adapts a traditional model of Cournot competition between rival producers of an illicit good that can sabotage each other and a government that can punish to raise costs. His model predicts that increased enforcement unambiguously reduces production/consumption and consumptionbased external costs such as domestic violence. ${ }^{1}$ Enforcement's effects on violence are ambiguous, depending on how closely interdiction efforts resemble interfirm sabotage. The more interdiction resembles extralegal sabotage, the greater the external violence costs. This result, too, has implications for South Carolina. Its interdiction efforts were sometimes arbitrary and often violent (Hendricks 1945b). As Flores (2016, p. 80) concludes, it remains an empirical issue whether violence increases in enforcement efforts. ${ }^{2}$

This paper exploits a unique liquor control experiment adopted in South Carolina in the 1890s to disentangle the countervailing effects of alcohol regulation and control. Because the South Carolina regulation of 1892/93, which did not rise to prohibition, was contested and differentially enforced across counties, it is possible to invoke a continuous difference-in-differences estimator in the spirit of Acemoglu, Autor and Lyle (2004) and Adorno (2007) to sort out the hypothesized deleterious enforcement effect (more market-based violence) from the salutary regulatory effect (less alcohol-induced violence).

The South Carolina results, which are robust to alternative specifications, control variables, and treatment windows, reveal that in the four years prior to the state's establishment of a monopoly in wholesale and retail alcohol sales there were, on average, 122 homicide prosecutions per year. In the subsequent decade the average number of prosecutions jumped to 212 per year. When county-level

\footnotetext{
${ }^{1}$ Boulding's (1947) simpler model yields the same conclusion regarding equilibrium consumption.

${ }^{2}$ Other models of drug markets also yield ambiguous predictions. Caulkins et al (2006), for example, show that if the largest economic rents are earned by the most violent sellers, any intervention that raises prices increases the incentives to use violence.
} 
homicide prosecution rates are regressed on county-level liquor law enforcement rates in a difference-in-differences approach, the results imply that a one standard deviation increase in enforcement prosecutions increased the homicide prosecution rate by about six per hundred thousand people, or $60 \%$ of the pre-monopoly era homicide prosecution rate of 10.1 per hundred thousand people.

The estimated $60 \%$ increase is robust to a number of alternative specifications and robustness checks. It persists with the inclusion of state prosecutor fixed effects and time trends. It persists with the inclusion of several demographic and contemporaneous criminal activity controls. It is also persists after controlling for what might be characterized as police "rousts," defined here as cases in which a defendant is arrested for an alcohol violation but a grand jury either refuses to indict or the prosecutor refuses to prosecute. Although the evidence does not directly address O'Flaherty and Sethi's (2010) war-zone hypothesis, it is consistent with their finding that modern drug prohibitions lead to more lethal violence.

The South Carolina experience adds to a handful of studies that attempt to sort out the countervailing effects on violence of Prohibition-era (1920-1933) policies in the United States. Miron (1999) and Jensen (2000) employ time-series models that regress murder rates on enforcement expenditures. They find that greater enforcement is associated with increased murder rates. These studies find a positive net increase in murder due to prohibition enforcement, but the results cannot be viewed as causal even though federal prohibition expenditures were independent of or exogenous to local murder rates.

Owens $(2011,2014)$ and Livingston (2016) exploit differences in the timing of state-level prohibitions, which predated federal prohibitions, to estimate more plausibly causal relationship using difference-in-differences approaches. Owens (2011) reports that state-level prohibition reduces the murder rate. Livingston (2016), too, finds that the murder rate declined in the first and second year after prohibition, and he finds no statistically significant effect at year four and beyond. He infers, but does not show, that this effect reflects consumer stockpiling of alcohol in 
anticipation of prohibition. Market-based crime occurred, if at all, only after stockpiles were exhausted. Owens (2014) investigates whether aggregate murder rates confound reduced alcohol-induced violence among some groups and blackmarket-based violence among others. Using age-disaggregated data she finds that murder rates increase for men in their twenties and decline for other age groups during prohibition. Because black-market-based violence is more likely among young men, Owens argues that the evidence is consistent with both the alcohol-induced and market-based violence hypotheses. The results reported below provide added support for her finding.

\section{South Carolina's dispensary system}

In 1893 South Carolina controlled liquor sales through a local-option law in which counties and incorporated municipalities determined by referendum whether saloons or taverns, separate from restaurants and hotels, would be licensed. No license could be granted outside an incorporated city, town, or village and saloon owners were made civilly liable for any injury to person or property by any minor, known alcoholic, or insane person served at a licensed saloon. Saloons were required to close at 6:00 P. M. In 188730 municipalities adopted the no-license rule (Blakey 1912, Plate 3). An estimated 700 to 800 saloons and taverns - independent of a

restaurant or a hotel - operated across South Carolina in the late 1880s (Eubanks 1950 , p. 57 ), or about 0.7 saloons per thousand people, which was less than one-half the national average. An unknown number of hotels, which were exempt from the license law, served alcohol, as well.

Eubanks (1950) claims that, despite the ready availability of alcohol through saloons and taverns, liquor and apothecary shops, and restaurants and hotels, bootlegging was rampant and "blind tigers" (Carolinian slang for illegal taverns) so common that liquor dealers themselves urged more rigorous enforcement to rid them of the competition. Evidence from the state's county court reports suggests that enforcement was spotty, at best. The state attorney general reported only four convictions and two mistrials statewide for selling liquor without a license in 1888; 
fewer than 10 cases were discontinued by state solicitors (SC Attorney General 1888).

Temperance societies and prohibitionists alike were dissatisfied with existing law and lax enforcement. A series of prohibition laws and amendments to the license system were proposed. Governor Benjamin Tillman opposed prohibition, in part because he considered it unenforceable and, in part, because he wanted to capture the profits of the alcohol trade for the state treasury. Tillman out-maneuvered the prohibitionists when he convinced his rural voting base that cities and towns took in license revenues but the costs of alcohol-related crime were paid by all taxpayers, including those residing in rural areas without (legal) saloons (Eubanks 1950). Instead of either a so-called high license system, which priced licenses beyond the reach of small taverns, or outright prohibition, Tillman offered an alternative Dispensary System in which the state itself would be the monopoly wholesaler and retailer of alcohol.

The principal feature of the original Dispensary act included a state board of control that appointed county control boards that, in turn, appointed a single dispenser for each county, except Charleston (10 dispensaries) and Richland (3 dispensaries) counties (Hendricks 1945a). The original act placed each county's dispensary at the county seat. Subsequent amendments allowed for additional dispensaries in some counties. The state commissioner purchased from domestic distillers, brewers, vintners and importers all liquor to be sold at the dispensaries. Liquor was delivered in bulk to the central dispensary in Columbia. The central dispensary then packaged the liquor into specially designed bottles in quantities not less than one-half pint and not greater than five gallons. The central dispensary then sold the sealed containers to local dispensaries at a maximum 50\% markup of net cost. County dispensers were appointed by the county dispensary board and paid a salary. Any profits generated at local dispensaries were divided equally between the county and the municipality in which the dispensaries were located.

Any person wanting to purchase alcohol had to file an application at a local dispensary. Dispensers were prohibited from selling to minors or known drunkards, 
or to people whose legal guardians or spouses requested that they be denied. Buyers could not open bottles on the dispensary premises. Sunday sales were prohibited, as were sales between 6:00 P.M. and 8:00 A.M. on other days. Tillman's purpose was not prohibition. His stated intentions were to eliminate sales of adulterated liquor, to increase state revenues, to eliminate the private profit motive from alcohol sales, and to reduce crime by taking alcohol sales out of saloons, gambling dens, and brothels. Opponents argued that the dispensary would do little to reduce consumption, raise little revenue for the state and municipalities, and it would encourage smuggling, moonshining, and bootlegging (Hendricks 1945a; Eubanks 1950).

The dispensary law went into effect on July 1, 1893 and the control board scrambled to get the system going. The state control board contracted with several distillers and breweries for product, and leased a warehouse in Columbia where the product was delivered by rail, repackaged, and distributed to county dispensaries. The control board later adopted some regulations not included in the original act. Sales were cash only; buyers could make only one purchase each day; and dispensary store fronts had to be open and well-lit so that anyone standing outside could see what was happening inside (Eubanks 1950, p. 71).

Resistance to the law took many forms. Some state, county, and local officials refused to enforce the law. Charleston's mayor publicly announced that he would not. City officials continued to issue licenses to private clubs and previously licensed saloons went underground and operated as blind tigers. Upscale blind tigers charged an entry fee, served drinks, and provided entertainment (Smith 2005). Downscale tigers were simple barrooms with entrances on alleys. One local newspaper editorial noted that the only real consequence of the law was that Charlestonians were now forced to "imbibe the red-tape cocktail" (quoted in Smith 2005, p. 204).

Two of the more controversial features of the dispensary act were that it gave the governor authority to appoint a state constabulary, which reported only to him, and the constabulary could engage in warrantless searches of homes and businesses if suspected violators might flee or easily dispose of contraband liquor (Christensen 
1908). If a raid resulted in evidence of a violation, a warrant could be obtained after the fact. During the first few years of the system, the governor appointed 75 constables at an annual cost of $\$ 66,000$ (Hendricks 1945b). Tillman responded to Charleston's mayor's refusal to enforce the law by dispatching several constables to do so. The mayor and police chief instructed city police to not assist the constables, but to not interfere either. The constables' enforcement efforts were further frustrated by grand juries that did not indict, state attorneys that did not prosecute, and juries that did not convict. Table 1 shows the disposition of liquor cases following arrests in Charleston and Spartanburg, two comparably populated counties that differed in public support for the law.

\begin{tabular}{|c|c|c|c|c|c|c|c|c|}
\hline \multicolumn{9}{|c|}{ Table 1} \\
\hline \multicolumn{9}{|c|}{ Charges, indictments and prosecutions for dispensary violations } \\
\hline & \multicolumn{4}{|c|}{ Charleston } & \multicolumn{4}{|c|}{ Spartanburg } \\
\hline & No bill & $\begin{array}{c}\text { Nolle } \\
\text { prosequi }\end{array}$ & $\begin{array}{l}\text { Not } \\
\text { guilty }\end{array}$ & Guilty & No bill & $\begin{array}{c}\text { Nolle } \\
\text { prosequi }\end{array}$ & $\begin{array}{l}\text { Not } \\
\text { guilty }\end{array}$ & Guilty \\
\hline 1893 & 11 & 1 & 0 & 0 & 0 & 0 & 0 & 5 \\
\hline 1894 & 4 & 77 & 0 & 0 & 4 & 2 & 0 & 3 \\
\hline 1895 & 21 & 3 & 1 & 0 & 3 & 1 & 5 & 17 \\
\hline 1896 & 74 & 229 & 1 & 31 & 19 & 5 & 0 & 24 \\
\hline 1897 & 104 & 75 & 4 & 4 & 16 & 8 & 2 & 17 \\
\hline 1898 & \multicolumn{8}{|c|}{ No data } \\
\hline 1899 & 60 & 25 & 2 & 0 & 0 & 0 & 4 & 11 \\
\hline 1900 & 118 & 3 & 0 & 0 & 0 & 1 & & 30 \\
\hline 1901 & 59 & 0 & 0 & 0 & 21 & 9 & 4 & 24 \\
\hline 1902 & 2 & 0 & 0 & 0 & 12 & 7 & 5 & 20 \\
\hline Total & 432 & 413 & 8 & 35 & 75 & 33 & 20 & 151 \\
\hline \multicolumn{9}{|c|}{$\begin{array}{l}\text { Notes: No bill = grand jury chose not to indict defendant arrested for violation. Nolle prosequi is } \\
\text { loosely interpreted as "I will not prosecute," and occurs when state solicitor informs the court at tria } \\
\text { that he is unwilling to try the case. Population in Charleston County in } 1900 \text { was } 88,000 \text {; Spartanburg } \\
\text { population was } 65,000 \text {. Attorney general did not report prosecution data in } 1898 \text { report. } \\
\text { Sources: author's calculations from South Carolina. Attorney General (1893-1902). }\end{array}$} \\
\hline
\end{tabular}

In the first decade of the dispensary system grand juries in Charleston chose not to indict more than 432 defendants held over for arraignment by a county magistrate. In 413 cases the prosecutor entered a nolle prosequi (commonly shortened 
to nol or nol pros and loosely interpreted as "I will not prosecute"), after which the case was discontinued. In South Carolina the nol determination was entirely at the discretion of the prosecutor; judges played no part in the decision and typically accepted the prosecutors' decisions to nol without question (Clary 2016). Nolled cases could be revived later, but rarely were. Compared to Spartanburg, Charleston's grand juries and prosecutors were less likely to indict or prosecute violations of the dispensary law. Of the cases actually prosecuted, petit juries were less likely to convict. In 1896 the governor was so frustrated by Charleston's unwillingness to enforce the law on its own, that he sent several constables with instructions to close the city's blind tigers.

In response to the difficulty of securing indictments and convictions in cities and counties in which the law was unpopular, the state legislature amended the original act. The amendments pushed the state attorney general's office to prosecute cases when local state prosecutors refused to do so. They also made it easier for prosecutors to secure a change of venue when grand juries refused to indict (Eubanks 1950).

While some Carolinians resisted the law through nonenforcement and others met its enforcement with violence (reports of violent constable-bootlegger interactions are readily found in the state's newspapers), the real challenge to Tillmans' dispensary law was constitutional. A majority of the state's three-member Supreme Court found the 1892 act unconstitutional within a few months of passage. The legislature responded in the 1893 session by passing a new law with only modest changes. In the interim one of the justices who considered the 1892 unconstitutional retired and the governor nominated a dispensary supporter to the bench. When the 1893 act was challenged, a majority of the reconfigured court found it constitutional and the dispensaries reopened on August 1, 1894 after a brief hiatus.

Unable to find relief in the state courts, opponents challenged the law in federal court. In early 1895 Federal Circuit Court Justice Simonton issued a temporary injunction because the dispensary act, which prohibited common carriers from transporting alcohol across state lines even if it was not intended for sale in the 
state, interfered with interstate commerce in alcohol (SC House and Senate 1894). Governor Evans directed dispensary officials to ignore the injunction and continue as before and for constables to be particularly vigilant because he believed the injunction would encourage the importation of liquor and still more legal challenges to the dispensary (Eubanks 1950, p. 324). In 1896, Judge Simonton further undermined the law when he ruled that the law was unconstitutional insofar as it prohibited the importation of alcohol for personal use. Because the dispensary was neither a prohibition nor an inspection law, it did not fall under the general police powers of the state to regulate imports. Dispensary constables continued to enforce the law. Dozens of fresh challenges worked their way through the state and federal courts, but the state prevailed in most when it was shown that the confiscated liquor was destined for resale rather than personal use.

Judge Simonton's 1896 decision prompted the legislature to amend the act requiring the state chemist to test all imported liquor, including that for personal use. The law was challenged and, again, Judge Simonton struck down the sections that applied to personal use as an unconstitutional restriction on interstate trade. Simonton's decision effectively enjoined the dispensary constabulary, and after several constables were jailed for contempt, the governor temporarily disbanded the force (SC House 1899). Some counties resumed issuing saloon licenses and the governor reported more than 300 licensed establishments in June 1897 and 650 licensed establishments in June 1898.

Meanwhile challenges continued in the courts. In 1897 Judge Simonton had found that the sections of the law that limited sales to daylight hours, no sales by the drink in unsealed containers, no drinking on the premises, no Sunday sales, and no sales to minors and drunkards to be constitutional. The issue was finally closed on May 8, 1898 when Chief Justice of the United States Melville Fuller, in Vandercook v. $V$ ance, wrote the majority opinion that upheld the constitutionality of the dispensary system nearly in its entirety. The court did, however, uphold Simonton's private-use exception. The dispensary constabulary was reorganized, licensed sellers were closed, and the dispensaries again became the monopoly distributors of alcohol in the state. 
Temperance and prohibitionist groups pushed their agenda on the premise that limiting public access to inexpensive alcohol would reduce poverty and crime. Temperance groups were quick to note that restrictions reduced arrests for public drunkenness, but some recognized the perverse effect might be to increase binge drinking. As Eubanks (1950, p. 191) notes, people took their bottles home and were "prone to get on more serious [drinking] sprees and commit more crimes of violence than if her had taken a few drink at a saloon and carried none away." Public concern with violence prompted the Attorney General to investigate and he produced a table (summarized in Figure 1) that reported the total number of homicide cases disposed of in the pre-1894 and dispensary (post-1893) eras. He reported a 75\% increase in the number of homicide cases (average of 122.6 before and 212.9 after) and a $40 \%$ increase in the average number of assault cases.

Figure 1

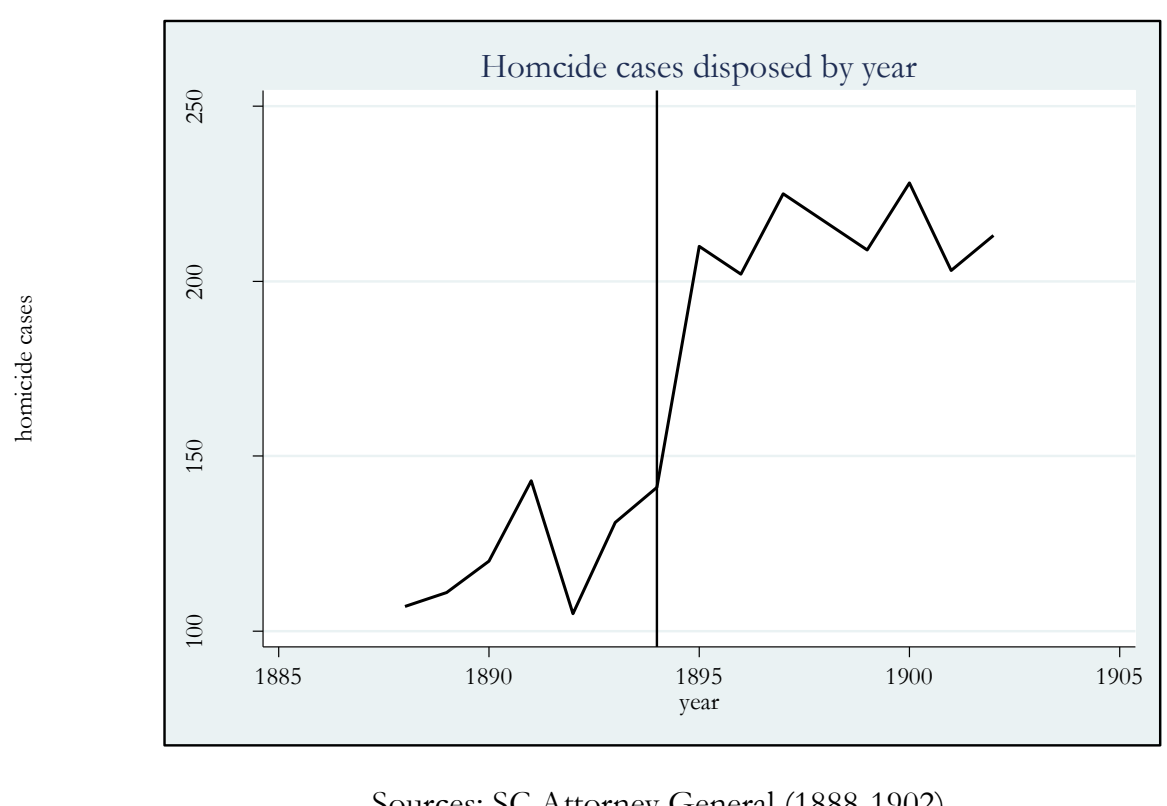

Sources: SC Attorney General (1888-1902).

"It was pointed out," writes Eubanks (1950, p. 191), "that the seeming decrease in [public] drunkenness and the actual increase in serious crime could be 
alike traced to the Dispensary's door." The increase in violence was attributed to the increase in bootlegging and moonshining, but Dispensary proponents expressed confusion over why this should be so. The official narrative concerning the dispensary system was that it sold unadulterated liquor at reasonable prices. And while it is likely that the dispensary sold chemically pure spirits, critics alleged it watered its liquor to increase profit margins. Moreover, it is not clear that the monopoly dispensary sold the liquor people wanted, in convenient locations, at competitive prices. Table 2 reports gross sales, net profits and the net margin on sales for the local dispensaries for selected years. Net margins were high by modern standards in the wholesale trade (approximately $2 \%$ to $4 \%$ ) and increased 2.4 times between 1897, when the law's constitutional status was still uncertain, and 1905, when the only meaningful legal limit on the dispensary was the personal-exemption exemption. Margins at the local dispensaries are indicative of market power. Bootlegging followed from the dispensary's monopoly pricing. Monopoly prices invite competition when entry is difficult to deter and black market activity is remunerative.

An additional incentive for bootleggers to enter the illegal liquor sector was the dispensary's failure to provide the types and qualities demanded. The central dispensary bought domestic rye, bourbon, gin, and rum in bulk then packaged, labeled, and priced them on a three-grade scale. In 1896 a pint of X-grade bourbon sold for 20 cents; XX for 25 cents and XXX for 30 cents. The central dispensary paid \$1 per gallon at wholesale, or 12.5 cents per pint for grade X (New York Times 1896). A legislative investigation into dispensary corruption uncovered two systemic problems. First, demand was greatest for the lowest grade, lowest-priced liquor, but margins for both distillers and dispensers were also lowest on X-grade alcohol. Distillers paid legal rebates and illegal kickbacks to the dispensary's purchasing agents in return for purchases of grade XX and XXX liquors. But local dispensers complained that they faced shortages of low-cost liquor and ended up with excess inventories of higher grades. Second, when the dispensary did purchase X-grade liquor, they watered it. Further, they sometimes distributed less-watered X-grade as 
XX-grade. Local dispensers paid the central dispensary $\$ 1.60$ per gallon for watered $\mathrm{X}$, which widened the central dispensary's margins, but increased demand for higher quality bootleg liquor.

\begin{tabular}{|c|c|c|c|c|}
\hline \multicolumn{5}{|c|}{ Table 2} \\
\hline \multicolumn{5}{|c|}{ Local dispensary average net margins } \\
\hline Year & Dispensaries & $\begin{array}{l}\text { Gross } \\
\text { sales }\end{array}$ & $\begin{array}{l}\text { Net } \\
\text { profits }\end{array}$ & $\begin{array}{c}\text { Net } \\
\text { margins }\end{array}$ \\
\hline & $\#$ & $\$$ & $\$$ & $\%$ \\
\hline 1897 & 90 & $1,252,289$ & 84,783 & 6.8 \\
\hline 1898 & 93 & $1,358,989$ & 91,716 & 6.7 \\
\hline 1899 & \multicolumn{4}{|c|}{ no report available } \\
\hline 1900 & 92 & $2,421,840$ & 270,160 & 11.2 \\
\hline 1901 & \multicolumn{4}{|c|}{ information not reported } \\
\hline 1902 & 103 & $2,406,214$ & 382,683 & 15.9 \\
\hline 1903 & 110 & $2,817,999$ & 455,647 & 16.2 \\
\hline 1904 & 111 & $3,374,786$ & 543,372 & 16.1 \\
\hline 1905 & 109 & $3,556,713$ & 590,199 & 16.6 \\
\hline $\begin{array}{l}\text { otes: } n \\
\text { urces: }\end{array}$ & $\begin{array}{l}\text { argin }=\text { net } p \\
\text { h Carolina. }\end{array}$ & $\begin{array}{l}\text { / gross sa } \\
\text { 3oard of C }\end{array}$ & (1897-19 & \\
\hline
\end{tabular}

South Carolina's dispensaries were also insulated from legal liquor imported from neighboring states. Georgia enacted a county-level local-option law in 1885 (Szymanski 2003, p. 144). By 1887 every Georgia county bordering South Carolina was dry (Blakely 1912). The nearest wet counties in Georgia were in the northwestern corner near the Tennessee-Alabama border. In 1883 North Carolina adopted local option. Although few counties went completely dry, by 1887 nearly every sizeable municipality in the counties contiguous to South Carolina or near the border were dry. By contrast, only 30 of South Carolina's municipalities prohibited liquor sales under its 1882 local-option law, 21 of which were located in the western up-country counties.

Various ruses were used to legally circumvent the dispensary but few succeeded. In 1913 the state chemist reported that his office had tested 19 different beverages labeled as "cider" and "near beer" that claimed to be alcohol free. Of these, just five beverages were $1 \%$ or less alcohol by volume; 12 were $5 \%$ or more, 
and two were $12 \%$ or more alcohol by volume (SC Commissioner of Agriculture 1913, p. 158).

South Carolina's dispensary system, by limiting the availability of a highly desired good, created a system in which corruption and law-breaking were rife. An upcountry moonshining culture expanded during the era. Smuggling and bootlegging were common and various ruses, such as mislabeling alcohol as cider and near beer, were employed to circumvent the law. Physicians prescribed and drug stores sold medicinal alcohol as treatments for everything from the common cold to cancer. Restrictions also increased violence at all levels of society. In one notable instance, J. Dudley Haselden, a member of the State Board of [Liquor] Control, was accused by newspaperman Ben Sellers of running a private saloon in his own home stocked with free liquor provided by the distillers' salesmen (New York Times, December 24, 1899). Haselden took exception to Sellers' exposé, gathered two friends and some weapons and visited Sellers. Sellers emerged from the fight with a gunshot wound to the stomach, his father was wounded in the arm; Haselden suffered a rifle shot to the leg and one of his friends took a nonfatal shotgun discharge in the back.

If disputes over the dispensary system elicited potentially deadly violence between government officials and newspapermen, it is not unreasonable to expect violence among those engaged in the illicit distribution of alcohol in an area of the US long-recognized for its reliance on extralegal violence to resolve disputes (Ayers 1984). Monopoly pricing, in addition to the adulteration and dishonest labeling of

alcohol, invited bootleggers who offered different, cheaper, or honestly labeled goods into the market. The Charleston News and Courier (February 24, 1898), a longstanding critic of the dispensary system, labeled the entire system a "breeder of lawlessness, crime and unending strife."

\section{Data and empirical strategy}

To investigate the relationship between alcohol restriction and violence, data on homicide and liquor law violations are gathered from annual reports of South Carolina's Attorney General (AG). Each year the AG asked district State Solicitors 
(the equivalent of a district attorney in other jurisdictions) to forward information on the prosecution of felony cases handled in their circuits. For nearly a half-century beginning in 1888 the AG tabulated the information and reported it in a largely unchanged format. Appendix Figure A1 reproduces a representative page.

Rows in the tabulated crime reports listed the principal criminal categories of cases coming before the court. Common entries included arson, assault and battery, burglary, larceny, murder, robbery, and so on. Rows of principal interest for this analysis are those related to homicide, specifically murder and manslaughter, which are combined to form a variable labeled homicide prosecution. Murder and manslaughter are combined for two reasons: because some solicitors' reports combined them and they cannot be separated from the available information; and because many, if not most, manslaughter convictions originated as murder cases in which the defendant pleaded guilty, presumably to avoid the risk of a capital conviction. The tabulated crime reports include three columns of interest: Not Guilty, Mistrial, and Guilty. (The tables also include information on the disposition of convictions, namely, jail, penitentiary, death sentence, but these data are not used in the analysis.) Rowcolumn cells provide the number of relevant cases. Thus, a cell might report 10 murder convictions, or three liquor law acquittals.

A second set of rows of principal interest are those related to liquor law prosecutions. Before 1893 the most common liquor law violations are for unlicensed sales, sales to minors, and Sunday sales. After 1893 prosecutions were grouped together in a catch-all category labeled "Dispensary law" by most solicitors. To make the bomicide prosecutions and liquor law prosecutions comparable across counties and time, the numbers are converted to a rate per hundred thousand from interpolations of annual populations from the decennial federal censuses.

The variables studied in the existing literature are the murder rate and enforcement expenditures (Miron 1999; Jensen 2000; Owens 2011; Livingston 2016). The data used here differ from these standard variables, but are no less useful for an investigation of any connection between alcohol control and violence. One difference is the measure of violence. Typically, the dependent variable is the murder 
rate, or the number of reported murders per hundred thousand people. Information included in the AG reports is not the murder rate; rather, it is the homicide prosecution rate, which equals the number of individuals who stood trial for murder or manslaughter. The homicide prosecution rate may reveal more about participation in lethal violence than the murder rate in that the homicide prosecution rate includes all individuals for whom prosecutors and grand juries believed the evidence established a preponderant likelihood of the defendant's culpability. A preliminary search of local newspapers reveals that many homicides involved more than one defendant, so that, unlike the murder rate, which is based on a body count, the homicide prosecution rate is a participation rate rather than an outcome rate. Available data preclude construction of a murder rate, but the prosecution rate and the murder rate are likely to be highly correlated.

Two additional columns in the AG's reports also offer information into liquor law enforcement. The tables also include "No bill" and "Discontinued" columns. A case was "no billed" if a grand jury failed to indict based on the evidence presented by the prosecutor. A case was discontinued or nolled if a grand jury indicted a defendant, but the solicitor charged with prosecuting the case chose not to pursue it. No-bill and discontinued cases are combined to capture a "rousting" effect, where roust is defined as an act of harassment by the police (Oxford English Dictionary Online 2011). It is known, for example, that Charleston's local authorities engaged in little enforcement. Frustrated by Charleston's inaction, Governor Tillman declared that his liquor constabulary would turn the city dry and in 1894 and 1896/97 conducted liquor sweeps that resulted mostly in unprosecuted arrests (see Table 1). Some arrests during these sweeps surely represented legitimate violations, but the constables may have rousted suspects. These cases are included separately because enforcement efforts need not result in trials to alter the nature of black market relationships and dispute resolution mechanisms if rousts helped push the trade underground. Police sweeps may sufficiently disrupt black markets to induce violence. 
The history of the dispensary system also reveals that care must be shown in how the dispensary era is defined. The original act established the dispensary in mid1893; the 1893 revision reestablished the dispensary monopoly in legal sales in summer 1894; and the final US Supreme Court determination in 1898 upheld the law, nearly in its entirety. But it must also be recalled that, despite court injunctions instructing the dispensary constables to stand down, Governor Evans directed the constables to ignore the injunctions and to continue with enforcement activities until federal marshals jailed some constables for contempt in 1898. Between mid-1893 and 1898 the law was enforced, if differentially across time and space.

Given the time it took to get the dispensary operational, to hire and deploy the constabulary, and to resolve the legal challenges to the law it may appear that the dispensary does not provide the sharp, well-defined regulatory break typically invoked in a standard difference-in-difference approach. Table 3 parses the data based on four dates when it would be reasonable to expect a break in the liquor enforcement and liquor rousts series: (1) following passage of the original act in 1892, which took effect in mid-1893; (2) following passage of the amended act in 1893, which took effect in 1894; or, (3) following passage of the amended 1893 act reinforced by passage of the federal Whiskey Tax in 1894, which led to increased federal enforcement of federal tax law; (4) following Judge Simonton's personal-use exception in 1895; or (5) instead of two regimes, there may be three: one prior to the original act; one between the original act and the final Supreme Court finding; and one following the finding that law was constitutional.

The liquor prosecution, liquor roust, and homicide prosecution rates reported in Table 3, all point to a break in 1893, following July 1, 1893 implementation of the late-1892 act. The average liquor prosecution rate increased nearly fourfold in the first decade of the dispensary's operation relative to the five preceding years. The roust rate increased by more than 6.5 times; the homicide prosecution rate increased almost 1.5 times relative to the pre-dispensary period. If, instead of imposing an immediate effect, we allow a year to fully implement the dispensary and allow some time for households to consume stockpiles of alcohol, 
the before and after differences are approximately the same as using 1893 as the break point. Imposing a three-regime structure does not alter the interpretation of the dispensary era. Compared to the five years prior to the establishment of the dispensary, enforcement efforts, rousts and homicides all increased almost immediately afterwards.

\begin{tabular}{|c|c|c|c|c|}
\hline \multicolumn{5}{|c|}{ Table 3} \\
\hline \multicolumn{5}{|c|}{ Homicide, assault and liquor prosecution rates } \\
\hline & Obs & $\begin{array}{l}\text { Liquor prosecution } \\
\text { rate }\end{array}$ & $\begin{array}{l}\text { Liquor roust } \\
\text { rate }\end{array}$ & $\begin{array}{l}\text { Homicide prosecution } \\
\text { rate }\end{array}$ \\
\hline \multicolumn{5}{|c|}{ Two regimes } \\
\hline \multirow[t]{2}{*}{$1888-1892$} & 155 & 2.25 & 1.59 & 10.09 \\
\hline & & [6.19] & [4.94] & {$[9.01]$} \\
\hline \multirow[t]{2}{*}{ 1893-1902 } & 322 & $8.95^{* *}$ & $10.62^{* *}$ & $14.49 * *$ \\
\hline & & [14.03] & [29.98] & [9.98] \\
\hline \multicolumn{5}{|c|}{ Two regimes } \\
\hline \multirow[t]{2}{*}{$1888-1893$} & 180 & 2.35 & 1.62 & 10.43 \\
\hline & & [6.26] & [4.80] & {$[9.21]$} \\
\hline \multirow[t]{2}{*}{ 1894-1902 } & 297 & $9.45^{* *}$ & $11.36^{* *}$ & $14.66^{* *}$ \\
\hline & & [14.37] & [31.09] & {$[10.00]$} \\
\hline \multicolumn{5}{|c|}{ Three regimes } \\
\hline \multirow[t]{2}{*}{$1888-1892$} & 155 & 2.25 & 1.59 & 10.09 \\
\hline & & [6.19] & [4.94] & {$[9.01]$} \\
\hline \multirow[t]{2}{*}{$1893-1897$} & 163 & $8.49^{* *}$ & $11.21^{* *}$ & $14.34^{* *}$ \\
\hline & & {$[15.47]$} & [37.34] & [10.35] \\
\hline \multirow{2}{*}{ 1898-1902 } & 159 & $9.41 * *$ & $10.01 * *$ & $14.65^{* *}$ \\
\hline & & {$[12.41]$} & [19.89] & {$[9.62]$} \\
\hline
\end{tabular}

Notes: regimes refer to periods before and after the law was passed (1893) and periods when it was not clear whether the law was constitutional (1893-1898) and when the US Supreme Court finally upheld its constitutionality and the law was more strictly enforced. ** implies difference in means for years in question and pre-dispensary period at $\mathrm{p}$-value $<0.01$. Sources: author's calculation from South Carolina Attorney General (1888-1902).

\subsection{Empirical strategy}

Early studies of prohibition and violence used time series methods (Miron 1999; Jensen 2000), but recent studies adopt alternative strategies that consider temperance regulation or outright prohibitions as treatment effects that lend 
themselves to difference-in-differences (DiD) approaches (Owens 2011; Livingston 2016). This paper follows the latter strategy to take advantage of different levels of treatment in a post-regulatory change environment (Acemoglu, Autor and Lyle 2004; Adorno 2007) to estimate the effect of liquor law enforcement on the homicide prosecution rate in South Carolina.

Adorno (2007) shows how a continuous DiD approach can be implemented and interpreted. Let $h_{i}(L)$ represent the set of potential realizations of the homicide prosecution rate for each county indexed by $i$, given a random continuous liquor enforcement rate. It is assumed that homicide realizations in a county are independent of liquor enforcements and homicides in neighboring counties; that is, there are no spillovers in which enforcement in one county influences the homicide rate in other counties. For each county there is also a vector of covariates, $\mathrm{X}_{\mathrm{i}}$, that, as well as the level of liquor enforcement, $\ell_{\mathrm{i}} \in[0, \ell]=\mathrm{L}$, influences the homicide prosecution rate.

Following the DiD literature, the sets of potential outcomes can be separated into two groups $h_{i}(L)$ for all counties with positive treatment, $\left.\left.L \epsilon\right] 0, \ell\right]$, and $h_{i}(0)$ otherwise. The equations describing the set of potential homicide outcomes can be represented by the following:

(1) $h_{i}\left(\ell_{i}\right)=f^{L}\left(X_{i}, \ell_{i}\right)+\varepsilon_{i}\left(\ell_{i}\right)$ for $L>0$

(2) $h_{i}(0)=f^{0}\left(X_{i}, \ell_{i}\right)+\varepsilon_{i}(0)$ for $L=0$

the $\varepsilon_{\mathrm{i}}(\bullet)$ are mean zero error terms uncorrelated with $\mathrm{X}_{\mathrm{i}}$ and $\ell_{\mathrm{i}}$.

Adorno (2007) shows that estimation of an empirical specification consistent with Equations (1) and (2) provides an estimate of the average treatment effect, which can be written as:

(3) $\mathrm{ATE}=\alpha_{\mathrm{i}}=\mathrm{E}[\mathrm{h}(\mathrm{L})-\mathrm{h}(0)]$,

Thus, the ATE can be estimated by:

(4) $\alpha_{\mathrm{i}}=\mathrm{f}(\mathrm{L}, \mathrm{X}, \varepsilon)$.

The standard DiD equation is then modified and takes the following form: 
(5) homicide prosecution rate $\mathrm{tc}_{\mathrm{tc}}=\beta_{0}+\beta_{1}$ liquor prosecution rate $\mathrm{tc}_{\mathrm{tc}}+\beta_{2}$ dispensary $_{\mathrm{tc}}$ $+\beta_{3}$ liquor prosecution rate $_{\mathrm{tc}} *$ dispensary $_{\mathrm{tc}}+\beta_{4}$ Circuit $_{\mathrm{c}}+\beta_{5} \mathrm{X}_{\mathrm{ct}}+\varepsilon_{\mathrm{tc}}$,

where $\mathrm{c}$ indexes the county and $\mathrm{t}$ indexes time. The homicide participation rate is, as discussed in the previous section, the number of murder and manslaughter cases prosecuted per hundred thousand people in year $t$ and county $c$. The liquor prosecution rate is the number of liquor law violations prosecuted per hundred thousand. As in any differences-in-differences-type estimation, $\beta_{3}$ is the coefficient of principal interest. Under certain general conditions, it will provide consistent and unbiased estimate of the effect of dispensary enforcement on the population subject to enforcement (that is, it will estimate the average effect of the treatment consistent with Eq. (4)) (see also Lechner 2010 for a discussion of standard DiD estimation).

Baseline regressions are estimated with circuit fixed effects and with standard errors clustered on county. Circuit, rather than county, fixed effects are implemented because state solicitors oversaw prosecutions in their circuits, which included between three and five counties. Although local attitudes surely influenced enforcement efforts, it was the solicitors and their assistants who worked (or not) to secure grand jury indictments, chose which indicted defendants to prosecute, and chose the level of resources to devote to the prosecution of liquor cases. Thus, the circuit fixed effect captures differences in solicitor and, perhaps, judicial behaviors.

The $\mathrm{X}$ vector includes several county-level variables that may have influenced the homicide rate: population density, the fraction of the population that was black, the fraction of the population that was Baptist, and whether the county shared a border with North Carolina or Georgia. Population density is included because crime rates tend to be higher in cities (Glaeser and Sacerdote 1999). The percent black is included to account for the violence directed toward blacks in the Jim Crow era. The Historical American Lynching (HAL) Project (2016) documents an average of five known lynchings per year in South Carolina between 1882 and 1900. More than onethird of the lynched individuals were charged with murder or attempted murder, 
which supports the contention that South Carolina operated under a culture of violence and violent extralegal retribution, often directed toward blacks. The fraction of the population Baptist is included to capture any indirect effect between a preference toward abstinence and violence. Contemporary accounts emphasized the sharp religious and cultural distinctions between the Baptist upstate and Episcopalian Charleston, which was more tolerant of moderate alcohol consumption (Smith 2005). Border effects are included to account for the long history of moonshining culture in the southern Appalachians (Buseman 2002). In addition to repeatedly targeting Charleston's blind tigers, the dispensary constabulary maintained a visible presence at the borders, especially the Georgia border along the upstate counties. Heightened enforcement in border counties may have increased the number of black market disputes and increased violence in those counties.

Table 4 provides summary statistics for the five years before (1888-1892) and nine years after (1894-1902) passage of the dispensary act (1893 is dropped given that the initial law went into effect on July 1, 1893 and full establishment in July 1894). Homicide prosecution rates increase by nearly 4.5 per 100,000 after passage of the law, which represents a statistically significant and economically meaningful $32.5 \%$ increase. Liquor law prosecution and roust rates also increase in the decade after the system was put in place. The other characteristics, which, given their definition, evolve gradually (or not at all) over time are not significantly different in the two eras. 


\begin{tabular}{|c|c|c|c|}
\hline \multicolumn{4}{|c|}{ Table 4} \\
\hline \multicolumn{4}{|c|}{ Summary statistics } \\
\hline & 1888-1892 & 1894-1902 & $\mathrm{p}$-value \\
\hline \multirow{2}{*}{ Homicide rate } & 10.079 & 14.437 & \\
\hline & [9.175] & [9.441] & 0.000 \\
\hline \multirow[t]{2}{*}{ Liquor enforcement rate } & 2.279 & 9.887 & \\
\hline & [6.266] & [14.938] & 0.000 \\
\hline \multirow[t]{2}{*}{ Roust rate } & 1.642 & 11.786 & \\
\hline & [4.015] & [32.139] & 0.000 \\
\hline \multirow[t]{2}{*}{$\%$ black } & 0.577 & 0.579 & \\
\hline & {$[0.168]$} & [0.163] & 0.906 \\
\hline \multirow[t]{2}{*}{$\%$ Baptist } & 0.163 & 0.162 & \\
\hline & [0.088] & {$[0.086]$} & 0.910 \\
\hline \multirow[t]{2}{*}{ Pop / sq mile } & 42.642 & 45.554 & \\
\hline & [16.830] & [19.525] & 0.114 \\
\hline \multirow[t]{2}{*}{ NC border } & 0.287 & 0.271 & \\
\hline & {$[0.454]$} & {$[0.445]$} & 0.727 \\
\hline \multirow[t]{2}{*}{ GA border } & 0.213 & 0.207 & \\
\hline & {$[0.411]$} & {$[0.406]$} & 0.886 \\
\hline Observations & 150 & 266 & \\
\hline Source: see Table 3. & & & \\
\hline
\end{tabular}

\subsection{Threats to identification}

Regulatory reforms most well suited for DiD approaches are those adopted as if at random with respect to the outcome under study. A principal concern with the DiD approach is that regulatory reforms are responding to different trends in the outcome variable between treated and untreated units of observations. While it seems unlikely that the motivation behind temperance supporters and prohibitionists was a belief that alcohol restrictions would reduce the incidence of murder, some argued that by making alcohol less available alcohol restrictions might reduce the incidence of violence, especially domestic violence (Eubanks 1950). The AG reports 
provide no insights into domestic violence because prosecutions were not separately identified in the tables. ${ }^{3}$ A typical test for different trends in the outcome variable that may have elicited the regulatory response is to check the pre-treatment period for evidence of non-parallel trends.

Figure 2

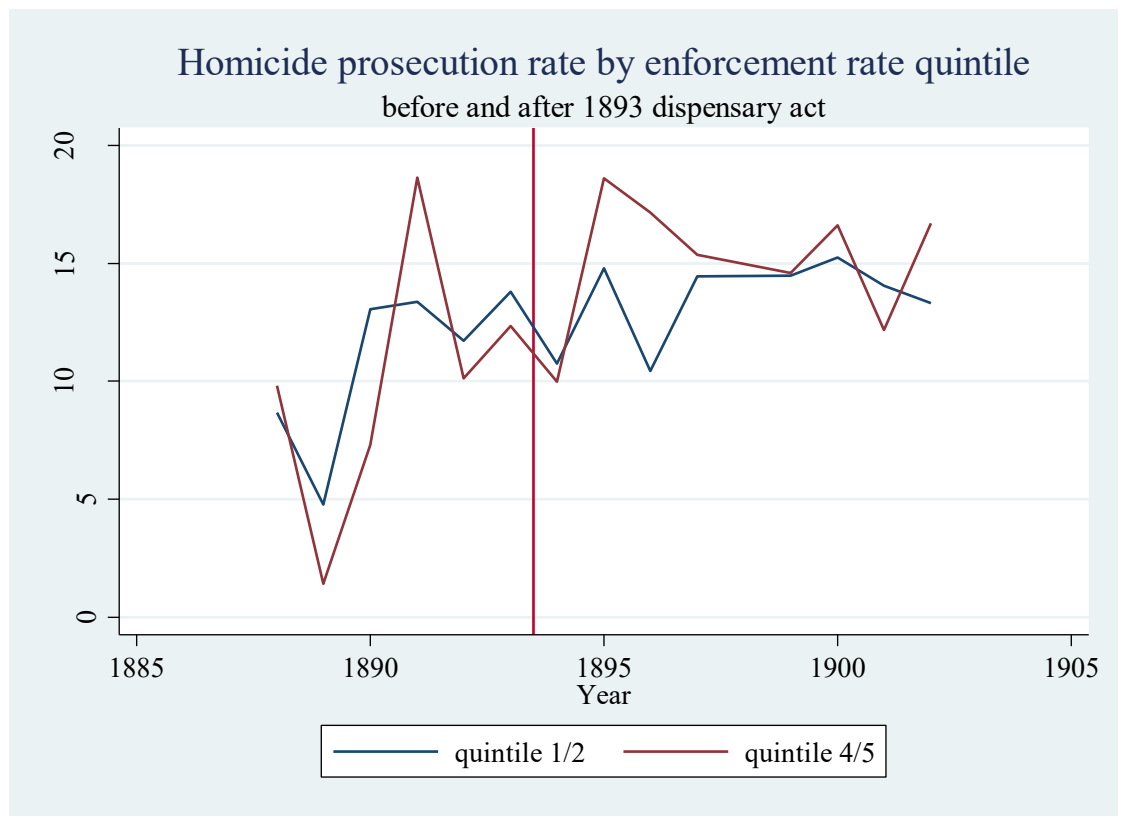

Sources: see Table 3.

To test for non-parallel trends, quintiles of liquor law enforcement rates were calculated for South Carolina's counties. Figure 2 compares movements in homicide prosecution rates for the two lowest and two highest quintiles. Although homicide rates are more variable in the two highest quintiles of liquor enforcement counties, there is no evidence that rates were following different trajectories either before or after the establishment of the dispensary. It seems safe to conclude that the state did not institute the dispensary system as a response to homicides.

\footnotetext{
3 Most "wife beating" and "child beating" cases were handled in municipal courts so that only particularly egregious instances of domestic violence were prosecuted in state courts as "Assault and battery." Information on municipal courts is unavailable, but assault prosecutions in state courts do not change after the dispensary goes into operation. The pre-dispensary assault prosecution rate is 22.8; the dispensary-era rate was 24.3. The change is small and statistically insignificant ( $\mathrm{p}$-value = $0.32)$.
} 
Given the continuous rather than dichotomous nature of the treatment variable, a second concern is whether enforcement varied in a systematic fashion that mimics a meaningful treatment. Figure 3 maps the average annual liquor law prosecution rate by county in the dispensary era. South Carolina can be divided into three distinct enforcement zones: the lightly enforced counties in the Low Country Pee Dee regions (the counties on or near the Atlantic coast); the barely enforced Midlands or Santee district; and the relatively heavily enforced Upcountry counties surrounding the cotton-mill district of the modern Anderson-Greenville-Spartanburg MSA. Thus the counties and solicitor's circuits that devoted more resources to enforcement are not geographically random, and there is sufficient systematic, persistent difference in enforcement to identify an average treatment effect. Some counties were more heavily treated than others.

Figure 3

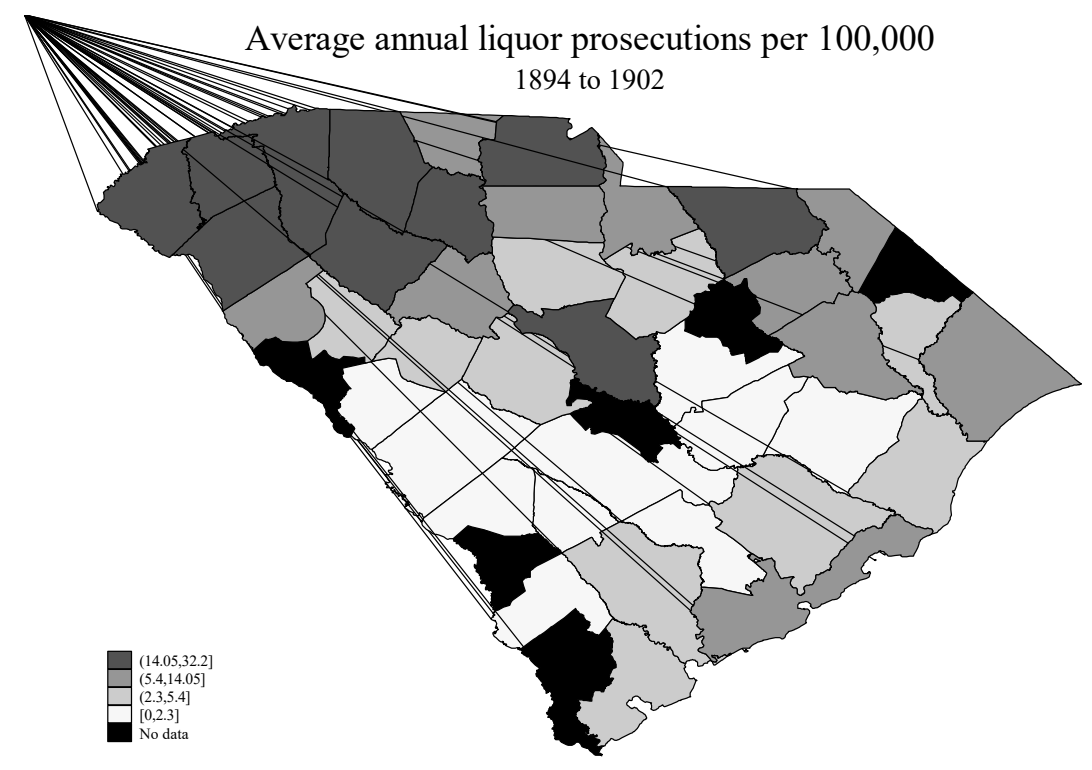

Sources: see Table 3.

Enforcement in South Carolina reflects national trends in that temperance movements gained more traction in less urbanized places and in places with more evangelical Christians (Owens 2011; Okrent 2010). And although public opinion toward saloons was overwhelmingly negative, places with more taverns and saloons 
were less likely to support temperance regulations or prohibitions. The concern here is whether dispensary enforcement was endogenous to the level of violence or some third variable correlated with both. If officials, for example, stepped up liquor law enforcement in response to increases in violence, the resulting estimates will be biased.

\begin{tabular}{|c|c|c|c|c|c|c|}
\hline \multicolumn{7}{|c|}{ Table 5} \\
\hline \multicolumn{7}{|c|}{ Determinants of county-level liquor enforcement } \\
\hline & (1) & (2) & (3) & (4) & (5) & (6) \\
\hline \multirow[t]{3}{*}{ Variable } & Summary & Probit & OLS & Summary & Probit & OLS \\
\hline & Statistics & $(\mathrm{dy} / \mathrm{dx})$ & & statistics & $(\mathrm{dy} / \mathrm{dx})$ & \\
\hline & & All years & & & 1894-1902 & \\
\hline \multirow[t]{2}{*}{ Homicide prosecutions } & 13.291 & 0.005 & 0.102 & 14.791 & 0.004 & 0.104 \\
\hline & [9.946] & {$[0.002]^{*}$} & {$[0.084]$} & [9.953] & {$[0.003]$} & {$[0.093]$} \\
\hline \multirow[t]{2}{*}{ Homicide prosecutions $(-1)$} & 12.811 & 0.001 & 0.176 & 14.525 & 0.002 & 0.244 \\
\hline & {$[9.617]$} & {$[0.003]$} & [0.089] & [9.403] & {$[0.004]$} & {$[0.121]$} \\
\hline \multirow[t]{2}{*}{$\%$ black } & 0.563 & 0.04 & -11.269 & 0.566 & 0.31 & -8.043 \\
\hline & {$[0.157$} & {$[0.286]$} & {$[8.060]$} & {$[0.155]$} & {$[0.330]$} & [10.691] \\
\hline \multirow[t]{2}{*}{$\%$ Baptist } & 0.167 & 0.136 & -9.914 & 0.166 & 0.31 & -12.913 \\
\hline & {$[0.085]$} & {$[0.322]$} & [9.546] & {$[0.085]$} & {$[0.347]$} & [13.749] \\
\hline \multirow[t]{2}{*}{$\%$ vote pro-Dispensary } & 0.632 & 0.11 & -0.829 & 0.632 & 0.085 & -1.647 \\
\hline & [0.411] & {$[0.061]$} & {$[1.211]$} & {$[0.415]$} & {$[0.079]$} & {$[1.925]$} \\
\hline \multirow[t]{2}{*}{ Pop / sq mile } & 45.562 & 0.004 & 0.088 & 46.434 & 0.004 & 0.112 \\
\hline & [19.219] & {$[0.002]^{*}$} & {$[0.052]$} & [20.048] & {$[0.002]^{*}$} & {$[0.052]^{*}$} \\
\hline \multirow[t]{2}{*}{ North Carolina border } & 0.297 & 0.074 & 4.94 & 0.287 & 0.044 & 7.35 \\
\hline & {$[0.458]$} & {$[0.084]$} & {$[2.207]$} & {$[0.453]$} & {$[0.106]$} & {$[3.322]^{*}$} \\
\hline \multirow[t]{2}{*}{ Georgia border } & 0.221 & 0.053 & 0.475 & 0.215 & -0.075 & -3.493 \\
\hline & {$[0.416]$} & {$[0.098]$} & {$[2.675]$} & {$[0.412]$} & {$[0.102]$} & {$[2.684]$} \\
\hline \multirow[t]{2}{*}{ Constant } & & & 3.338 & & & 0.163 \\
\hline & & & [7.430] & & & {$[8.718]$} \\
\hline Observations & 330 & & & 209 & & 209 \\
\hline F stat / Chi sq stat & & $63.6^{* *}$ & $15.1^{* *}$ & & $127.9^{* *}$ & $15.2^{* *}$ \\
\hline R-square & & 0.06 & 0.21 & & 0.12 & 0.35 \\
\hline Sources: author's calculations & & & & & & \\
\hline
\end{tabular}

Table 5 reports a simple test for the endogeneity of liquor prosecutions to contemporaneous and lagged homicide prosecutions, in addition to other covariates likely to influence the demand for liquor enforcement. Columns (1) and (3) report 
the summary statistics for the independent variables for all years and for the dispensary era alone, which include the proportion black, the proportion Baptists, the proportion of a county's state representatives that voted in favor of the dispensary act, and population density. The average county was 56\% black, 16\% Baptist, had about 46 people per square mile, and nearly two thirds of its representatives voted for the dispensary. Columns (2) and (4) report estimated marginal effects from probit regressions in which the dependent variable equals zero if there are no liquor prosecutions in a county-year, and one if there are any prosecutions. The estimated marginal effects reveal that the liquor enforcement efforts were generally unresponsive to current and lagged homicide prosecutions. Columns (3) and (6) report OLS estimates of liquor enforcement rates on current and lagged homicide prosecutions. The estimated coefficients on lagged prosecutions are not statistically significant at standard levels $(\mathrm{p}<0.05)$ and the estimates imply a modest effect. A one standard deviation increase in lagged homicide prosecutions increases current liquor enforcement by just $15 \%$ of its standard deviation.

A third point of concern is the appropriate length of the estimation period. A DiD approach provides unbiased estimates of the effect of a regulatory change so long as no other confounding factors change in the relevant window. A long window is likely to allow confounding effects to bias the estimates. Yet, regression analysis requires a sufficiently large number of observations to generate precise estimates of any true effect of a regulation. The unit of observation used here is the county; South Carolina had 41 in 1900, but there are fewer than 41 in some years because some state solicitors failed to report to the attorney general. The main results use relatively narrow two- and three-year windows before and after 1893, which is excluded because the law went into effect on July 1, 1893.

\section{Alcohol control and homicide prosecutions}

Figure 4 provides a scatterplot of the liquor-law and homicide prosecution rates before and after the adoption of the dispensary system. It illuminates the 
differential effects of enforcement efforts under alternative regulatory regimes. In the pre-dispensary era, when liquor was readily available, increased enforcement efforts, which were mostly aimed at suspects who sold on Sundays, without a license, or to minors, reduced the homicide prosecution rate. In the pre-dispensary era, moonshine interdiction was a predominantly federal effort, whose officials were more interested in collecting taxes than in shutting down production (Buseman 2002, p. 18). In the dispensary era, by contrast, increased enforcement efforts, which were mostly aimed at disrupting production and distribution, increased homicide prosecution rates.

Figure 4

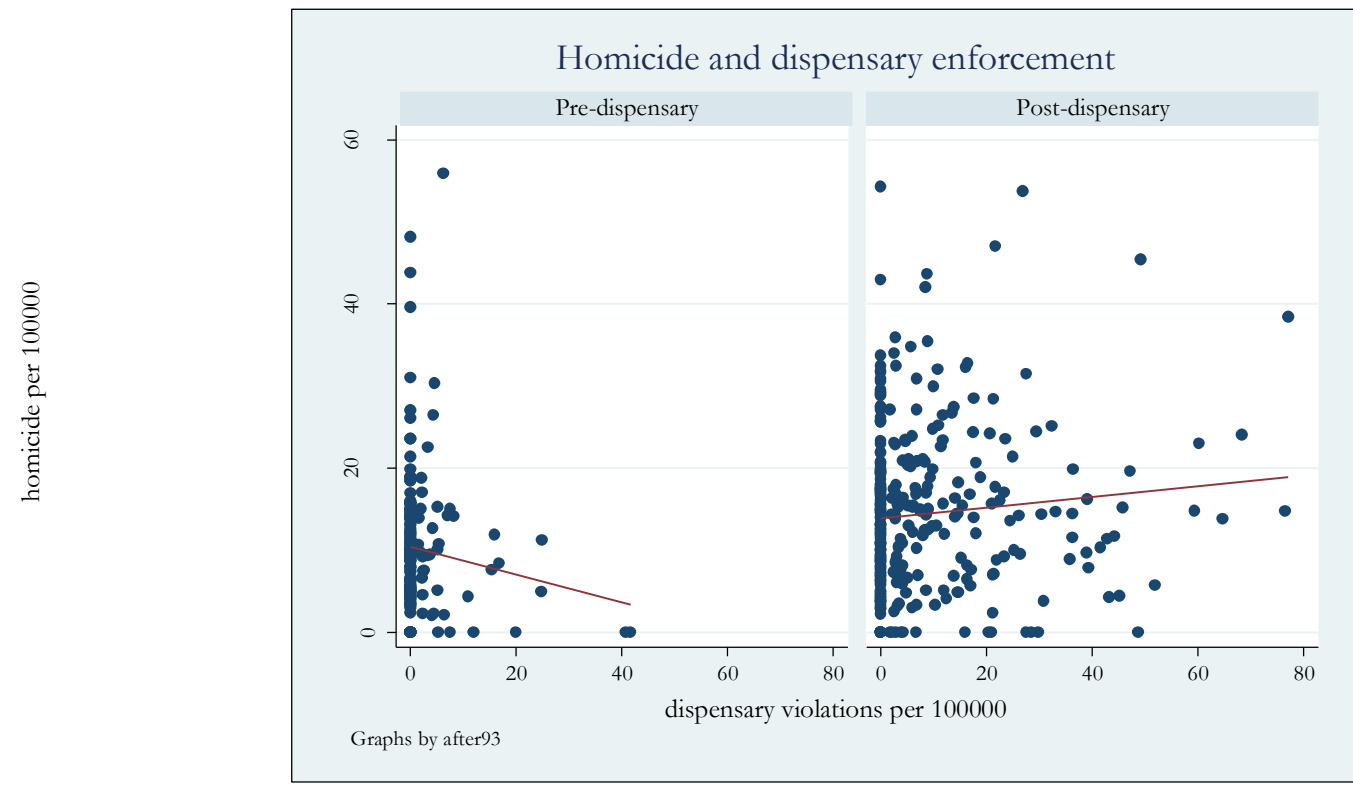

Sources: see Table 3.

\subsection{Baseline estimates}

Figure 4 illustrates the identification strategy for the formal empirical analysis in which post-dispensary enforcement is a continuous rather than dichotomous variable. Table 6 reports baseline estimates with different control variables and over two windows. Columns (1) through (3) use the two years prior and the two year after 
the full implementation of the dispensary. Columns (4) through (6) use three years before and after implementation. The issue is whether and to what extent increased liquor law enforcement led to an increase in the homicide rate. The results suggest a relatively large effect. In a traditional DiD approach with a simple on/off treatment, the coefficient of interest is the interaction term Post*Enforcement, which captures the effect of the treatment on the treated. But a continuous treatment accounts for the fact that some county-years experienced zero treatments (e.g., Charleston in most years), other county-years experienced intensive treatment (e.g., Spartanburg in most years), while other county-years experienced moderate but variable treatments. Thus, a continuous approach offers some subtleties of interpretation that a dichotomous treatment does not.

Coefficients on the Post*Enforcement variable in the two-year window, Columns (1) through (3), imply that a one-standard deviation change (19.4 prosecutions per hundred thousand) in enforcement in the dispensary era increases the estimated homicide prosecution rate by between 5.0 and 7.2 per hundred thousand. But the coefficient on Post also implies an increase in the homicide rate by an additional 0.9 to 1.9 per hundred thousand. The net marginal effect of the dispensary on homicides $\left[\partial(\bullet) / \partial\right.$ post $\left.\left.\right|_{\text {enforcement=k }}\right]$ in the first two years after full implementation, by which time consumer stockpiles were likely to have been exhausted was to increase the homicide prosecution rate by between 6.8 and 8.1 per hundred thousand. Given an unconditional mean homicide prosecution rate of 10.1 per hundred thousand in the pre-dispensary era, the human costs of the dispensary were high. Reducing the availability of alcohol and thereby encouraging an expansion of a violent moonshining and bootlegging culture led to an increase in the homicide prosecution rate (and, by implication, the murder rate) by about $60 \%$ to $80 \%$. 


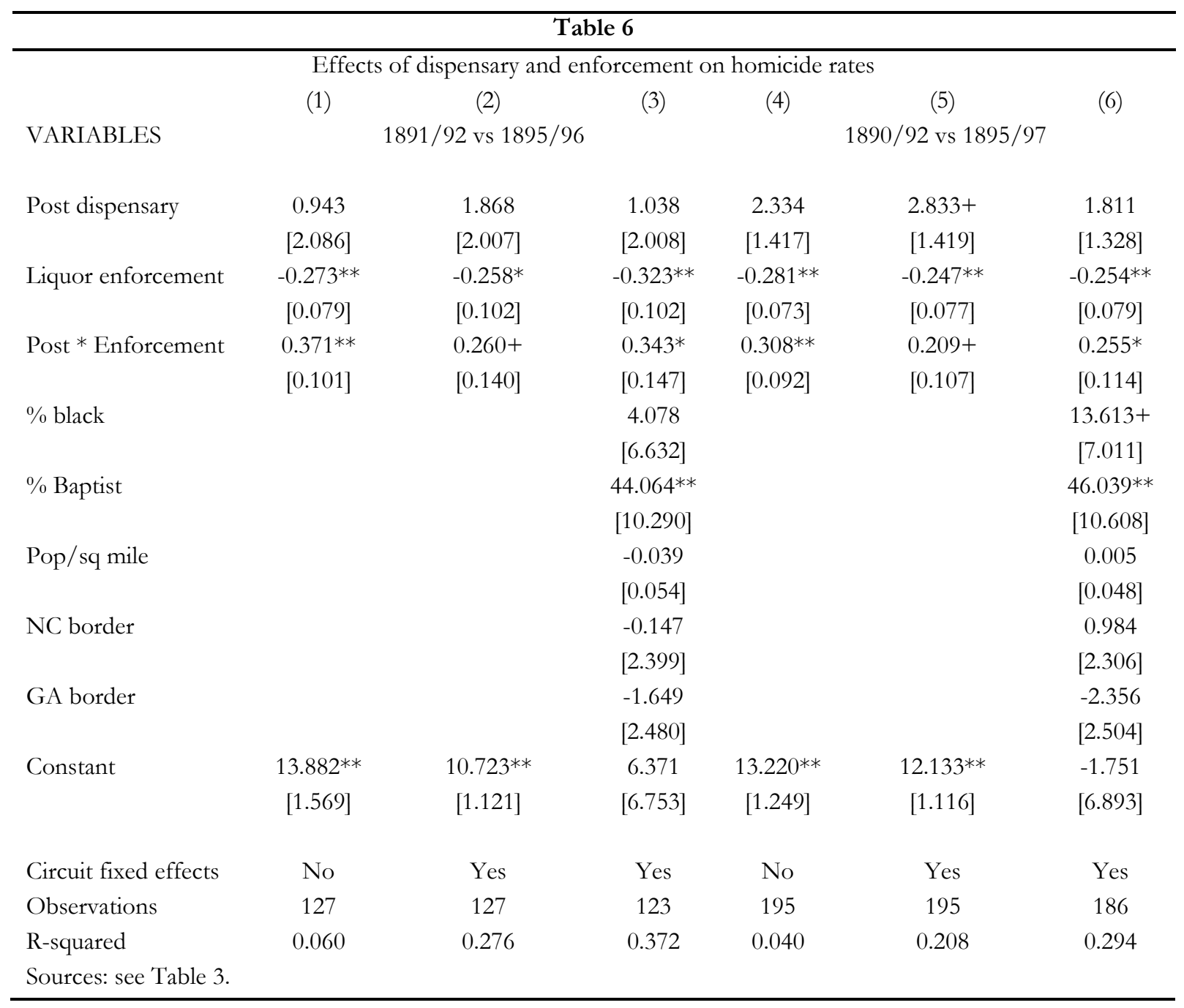

Columns (4) through (6) report estimated coefficients for the three years prior and the three years after full implementation of the dispensary, recognizing that the system was in full operation for only part of 1897. Despite its only partial operation, the number of dispensary prosecutions is approximately the same as in subsequent years, by which time enforcement efforts remained at levels about onehalf of those in the peak year of 1896. Here, again, the estimated coefficients imply an economically meaningful effect of liquor law prosecutions on homicides. A one standard deviation increase in the liquor law enforcement rate after implementation of the dispensary increased the homicide prosecution rate by between 3.6 and 5.5 per 
hundred thousand, or a one-third to one-half increase over the pre-dispensary rate. If we take into account the full post-dispensary effect by adding estimated coefficients on post, the estimated effect is to increase the homicide rate by 6.4 to 7.8 per hundred thousand.

\subsection{Was there a "rousting" effect?}

To this point, the analysis associates liquor law prosecutions with homicide rates and is consistent with the market-based violence hypothesis in that greater enforcement leads to greater violence. But it is not uncommon for police and other enforcement agencies such as the dispensary constabulary to engage in coordinated raids and neighborhood sweeps of suspects fully aware that some (potentially substantial) fraction of those arrested during the sweep will not be prosecuted. In common parlance, police engage in rousts designed to preempt or disrupt criminal activity. One issue surrounding rousts is whether they have net beneficial effects in reducing crime or whether they generate unintended consequences. It is possible, given Flores (2016) theoretical result, that if coordinated raids and sweeps disrupt black markets, the disruption may lead to increased violence.

Table 7 introduces Rousts an additional independent variable in the homicide rate regressions. A county-year roust value equals the sum of cases in which a grand jury failed to indict (no bill) and those in which a prosecutor failed to prosecute following an indictment (nolles), expressed as a rate per hundred thousand population. The principal coefficient of interest in Columns (1) and (2) are those on Post*Roust, which is statistically significant and economically meaningful in each specification. A one standard deviation increase in rousts $(=47.87)$ in the two year post-establishment period implies an increase in the homicide prosecution rate of 11.8 to 14.1 per hundred thousand. The 11.8 value represents a doubling of the predispensary homicide prosecution rate. Inclusion of the Roust variable in the two-year before and after window, however, reduces the magnitude and statistical significance of the Post*Enforcement coefficient, which may be due to collinearity between the Liquor and Roust variables (Pearson correlation coefficient $=0.35$, $\mathrm{p}$-value $=0.00$ ). 
Moreover, the null hypothesis that the two coefficients are equal cannot be rejected $(\mathrm{Z}$ statistic $=0.33)$, or that the violence-inducing effect of rousts and prosecutions are equal.

\begin{tabular}{|c|c|c|c|}
\hline \multicolumn{4}{|c|}{ Table 7} \\
\hline \multicolumn{4}{|c|}{ Evidence of a rousting effect } \\
\hline & (1) & (2) & (3) \\
\hline \multirow[t]{2}{*}{ VARIABLES } & & $\begin{array}{c}1891 / 92 \mathrm{v} \\
1895 / 96\end{array}$ & \\
\hline & Rousts & Rousts & Arrests \\
\hline \multirow[t]{2}{*}{ Post dispensary } & 0.509 & 0.514 & 0.371 \\
\hline & [2.193] & {$[2.137]$} & {$[1.973]$} \\
\hline \multirow[t]{2}{*}{ Liquor enforcement } & -0.129 & $-0.229+$ & \\
\hline & {$[0.115]$} & {$[0.131]$} & \\
\hline \multirow[t]{2}{*}{ Post*Enforcement } & $0.242+$ & 0.233 & \\
\hline & {$[0.128]$} & {$[0.166]$} & \\
\hline \multirow[t]{2}{*}{ Roust } & $-0.312^{* *}$ & $-0.224 *$ & \\
\hline & {$[0.095]$} & {$[0.098]$} & \\
\hline \multirow[t]{2}{*}{ Post*Roust } & $0.295^{* *}$ & $0.248^{*}$ & \\
\hline & {$[0.095]$} & {$[0.103]$} & \\
\hline \multirow[t]{2}{*}{ Arrests } & & & $-0.225^{* *}$ \\
\hline & & & {$[0.058]$} \\
\hline \multirow[t]{2}{*}{ Post*Arrests } & & & $0.245^{* *}$ \\
\hline & & & {$[0.067]$} \\
\hline Circuit fixed effects & No & Yes & Yes \\
\hline Observations & 127 & 123 & 123 \\
\hline R-squared & 0.080 & 0.385 & 0.385 \\
\hline
\end{tabular}

Column (3) then combines the Liquor and Roust variable into a single Arrest variable, which represents the total number of dispensary violations that led to an arrest in a county-year. In the two-year period after establishment of the dispensary, a one standard deviation increase in liquor violation arrests increased the homicide prosecution rate by 14.4 per hundred thousand, or $142 \%$ of the pre-dispensary rate.

\subsection{Robustness analysis - fixed-effects estimates}


Given the panel nature of the data and the paucity of time varying controls, a fixed-effect approach can be used to estimate the effect of liquor enforcement on homicide prosecutions. The identifying assumption for fixed effects models is that unobservable factors that might simultaneously affect the left- and right-hand side of the regression are time-invariant. In this case, the assumption appears to be innocuous in that it is unlikely that public preferences toward alcohol changed abruptly. Counties in which a majority of voters voted in favor of prohibition in the 1880s were counties for which a majority of their state representatives voted in favor of the dispensary in the $1890 \mathrm{~s}$ (Pearson correlation coefficient $=0.52, \mathrm{p}$ value<0.001). But liquor law enforcement did change abruptly after 1893. In such instances, fixed-effects models can be used to control for time-invariant differences between individual counties, and the resulting estimates provide estimates of the within county consequences of increased liquor enforcement.

\begin{tabular}{lcccc}
\hline \multicolumn{5}{c}{ Table 8 } \\
\hline \multicolumn{1}{c}{ Fixed effects estimates of liquor } & prosecutions & & \\
& $(1)$ & $(2)$ & $(3)$ & $(4)$ \\
VARIABLES & Homicide & Homicide & Homicide & Homicide \\
& & & & \\
Liquor enforcement & 0.050 & 0.020 & 0.056 & 0.027 \\
& {$[0.045]$} & {$[0.054]$} & {$[0.046]$} & {$[0.055]$} \\
Post dispensary & $4.044^{* *}$ & $6.038^{* *}$ & $3.885^{* *}$ & $6.223^{* *}$ \\
& {$[0.959]$} & {$[1.799]$} & {$[0.981]$} & {$[1.804]$} \\
Constant & $10.082^{* *}$ & $9.308^{* *}$ & $10.108^{* *}$ & $9.130^{* *}$ \\
& {$[0.556]$} & {$[1.349]$} & {$[0.573]$} & {$[1.385]$} \\
Year FE's & & & & \\
Charleston excluded & No & Yes & No & Yes \\
Observations & 452 & No & Yes & Yes \\
R-squared & 0.058 & 0.136 & 0.055 & 0.136 \\
Number of counties & 40 & 40 & 39 & 39 \\
\hline
\end{tabular}

Table 8 reports fixed-effects coefficients estimated from parsimonious models that include only the liquor law enforcement rate and an after 1892 dummy 
variable, which accounts for potentially abrupt changes coincident with the establishment of the dispensary. Models are estimated with and without individual year effects. Individual year effects should be included when unexpected variation or special events may affect the outcome variable (Torres-Reyna 2007), but it may be that the establishment of the dispensary is the single most important event during this period. The models are estimated with and without Charleston County in the panel because enforcement in Charleston was contested, highly variable, and motivated by partisan rivalries not present (to the same extent, at least) in other parts of the state. The regressions exclude 1893 because the dispensary opened in July, so the data from that year confounds pre- and post-dispensary effects. Standard errors are clustered on county; bootstrapped standard errors are not notably different.

The fixed-effects estimates offer a slightly different interpretation of the effect of the dispensary system on homicide prosecutions, but are broadly consistent with the DiD interpretations. Although the coefficients on liquor enforcement per hundred thousand are not precisely estimated, the coefficients imply that a onestandard deviation increase in enforcement is consistent with an increase in the homicide prosecution rate of between 0.25 and 0.70 per hundred thousand, or between $2.5 \%$ and $7.0 \%$ of the pre-dispensary rate. But, like the DiD estimates, estimated coefficients on the After1893 variable implies a discrete and permanent increase in the homicide prosecution rate of 3.9 and 6.2 per hundred thousand coincident with the establishment of the dispensary, or 39 to 62 percent of the mean pre-dispensary homicide prosecution rate.

\subsection{Robustness analysis - instrumental variables}

An alternative approach to estimating the effect of increased liquor law enforcement on homicide is to employ an instrumental variable or two-stage least squares approach. Due to omitted variables, reverse causality, or the possibility that some unobserved factor is causing both increased liquor enforcement and increased homicide prosecutions, estimates will be potentially biased if the independent variable of interest is correlated with the error term. One way to generate a 
consistent estimate of the enforcement-homicide effect is to identify one or more instrumental variables correlated with the enforcement variable, but uncorrelated with the error term. The issue is whether such an instrument is available.

To be a valid instrument a variable must satisfy two conditions: relevance $\left(\operatorname{corr}\left[\mathrm{disp} /\right.\right.$ sqmile $_{\mathrm{i}}$, liquor enforcement $\left._{\mathrm{i}} \neq 0\right)$ and exogeneity $\left(\operatorname{corr}\left(\operatorname{disp} /\right.\right.$ sqmile $\left._{\mathrm{i}}, \mathrm{u}_{\mathrm{i}}\right)$ $=0$, where $\mathrm{u}_{\mathrm{i}}$ is the error term from the regression of enforcement on homicide rates. A valid instrument must also satisfy the exclusion restriction in that it is correlated to the homicide rate by way of its correlation with the enforcement rate.

One possible instrument for the liquor law enforcement variable is a variable defined as dispensary per square mile. Between 1893 and 1896, each county except Charleston and Richland counties, were allowed one dispensary located at the county seat. The dispensary per square mile variable is expected to be relevant because having a single dispensary not necessarily located in a county's most populous town increases the cost of obtaining legal alcohol more in large than in small counties. And the more costly it is to obtain alcohol legally, the more will be acquired illegally holding population and demand constant, which should elicit an enforcement response from officials interested in maximizing the returns to their enforcement efforts (Knowles, Persico and Todd 2001). The Pearson correlation coefficient between dispensary per square mile and liquor law enforcement rate is 0.14 (p-value $=0.002)$. The instrument should also satisfy the exclusion restriction because the choice of county seat was made years before and the legislature's choice to allocate one dispensary per county was a political concession unlikely to have been made in anticipation of a change in the homicide rate. The one exception may be the decision to allocate 10 dispensaries to Charleston in which it was well known that the majority of the population was opposed to any type of liquor control. Instrumental variables regressions, therefore, are estimated excluding Charleston from the analysis. The analysis is also restricted to 1894/95 and 1894-1896 because the dispensary commission began authorizing additional local dispensaries in late 1896, perhaps in recognition of the increase in crime attributable to the increased cost of obtaining legal alcohol. 


\begin{tabular}{|c|c|c|c|c|}
\hline \multicolumn{5}{|c|}{ Table 9} \\
\hline \multicolumn{5}{|c|}{ Instrumental variables estimates } \\
\hline & (1) & (1) & (2) & (2) \\
\hline VARIABLES & Enforcement & Homicide & Enforcement & Homicide \\
\hline \multirow[t]{2}{*}{ Liquor enforcement } & & 0.635 & & 0.710 \\
\hline & & [1.261] & & {$[0.634]$} \\
\hline \multirow[t]{2}{*}{$\%$ black } & -10.299 & 5.113 & $-28.782^{* *}$ & 14.146 \\
\hline & [7.052] & [11.877] & {$[10.667]$} & [17.143] \\
\hline \multirow[t]{2}{*}{$\%$ Baptist } & -7.105 & $37.209 * *$ & -18.329 & $49.241 *$ \\
\hline & {$[11,761]$} & [13.889] & [13.934] & [19.831] \\
\hline \multirow[t]{2}{*}{ Pop/sq mile } & $0.184^{*}$ & -0.213 & 0.162 & -0.143 \\
\hline & {$[0.074]$} & {$[0.258]$} & {$[0.097]$} & {$[0.157]$} \\
\hline \multirow[t]{2}{*}{ Dispensary / sq mile } & 1218.323 & & $3614.834 \dagger$ & \\
\hline & [1153.365] & & [1984.194] & \\
\hline \multirow[t]{2}{*}{ Constant } & 5.842 & 12.060 & $29.136^{* *}$ & -7.514 \\
\hline & {$[6.098]$} & [8.059] & {$[9.310]$} & [18.498] \\
\hline Year FE's & Yes & Yes & Yes & Yes \\
\hline Circuit FE's & Yes & Yes & Yes & Yes \\
\hline Observations & 61 & 61 & 94 & 94 \\
\hline F-stat / Wald chi-sq & $5.03^{* *}$ & $68.4^{* *}$ & $16.0^{* *}$ & $63.8^{* *}$ \\
\hline Wu-Hausman test stat & & 0.023 & & 1.71 \\
\hline R-squared & 0.385 & 0.402 & 0.451 & \\
\hline \multicolumn{5}{|c|}{ Notes: $\dagger$ implies p-value $<0.10$; $*$ implies $<0.05$, and $* *$ implies $<0.01$} \\
\hline
\end{tabular}

Table 9 reports the first- and second-stage coefficient estimates of the instrumental variables models. Because the IV models rely on smaller samples than the DiD and fixed-effects models, the coefficients are less precisely estimated. Still, the results are consistent with earlier estimates and may imply that they were subject to some downward bias. With only one instrument, we cannot perform a test of any over-identifying restrictions, but the F-statistic on the first-stage regression in the larger (1894-1896) sample satisfies the rule-of-thumb of 10, and the dispensary variable itself is barely significant at standard levels.

Although they are not precisely estimated, the second-stage regression coefficients on the Liquor enforcement variable imply an effect about twice the magnitude of those estimated using $\mathrm{DiD}$ and about 10 to 15 times the fixed-effect 
estimate. The statistically insignificant Wu-Hausman test statistics fail to reject the null hypothesis of exogeneity for the instrumented variable, so we may be reasonably confident that the liquor enforcement variable is determined exogenously. Regardless of the statistical procedure, the basic result holds. By increasing the costs of acquiring and consuming legal alcohol, South Carolina's dispensary system indirectly increased the homicide prosecution rate. The likely channel was that increased enforcement efforts squeezed black markets and fostered a culture of violence.

\section{Discussion and conclusions}

In 1921 Samuel Hopkins Adams, a critic of Prohibition, offered a rather prescient assessment of how it might unfold: "Under the old local-option plan a community decided whether or not it would have liquor. Under the new [prohibition law] it decides whether or not it will have the law" (Okrent 2010, p. 256). And not just the Prohibition law, but rather the rule of law more generally. Okrent (2010, p. 373) concludes that prohibiting alcohol promoted a culture of bribery, corruption, and violence. It may be time to set aside romantic notions of bootleggers as early $20^{\text {th }}$ century Robin Hoods for the more realistic portrayal of a ruthless Enoch "Nucky" Thompson in HBO's Boardwalk Empire. Any assessment of Prohibition needs to balance the benefits of the reduced availability of alcohol, including lower rates of alcoholism, alcohol-related decreases in long-term health, and increase productivity, against the human costs, which include consumers harmed by consuming adulterated liquor and those caught up in turf wars (Cook 2007; Warburton 1932). Calculating the benefits to South Carolinians of reduced availability is beyond the scope of this paper, but the human costs were not trivial. Homicide rates increased, which has generally detrimental welfare consequences.

A common thread that connected such disparate accounts of prohibition as the cinematic accounts of Elliott Ness's team of untouchables to serious journalistic accounts such as Wainwright's (2016) Narconomics to academic analyses such as O'Flaherty and Sethi's (2010) account of modern urban "war zones" is that wellmeaning but serious restrictions on highly desired goods are fraught with unintended 
consequences. Progressive Era reformers, including the prohibitionists, believed that the rise of urban violence in the late nineteenth century was fueled not just by rapidly increasing urban densities, but by the rapid proliferation of the saloon. Reformers considered saloons the problem and worked to outlaw or at least place onerous restrictions on them. The reformer's efforts, however, did little to reduce violence and, as Miron (1999) argued, may have exacerbated already high rates of urban violence.

South Carolina's liquor control experiment between 1893 and 1907 offers a unique opportunity to investigate the link between liquor control and violence. The results, which are robust to alternative specifications and control variables, reveal that average annual homicide prosecution rate, a reasonable measure of the murder rate, jumped by $75 \%$ after the opening of the dispensary. When county-level homicide rates are regressed on county-level liquor-law enforcements rates, the results imply that a standard deviation increase in enforcement increased the homicide prosecution rate by about 6 per hundred thousand people; this is more than one-half the pre-dispensary era homicide prosecution rate of 10 per hundred thousand people. Liquor law prosecutions, however, had a trivial effect on the assault rate. Although the evidence does not directly address O'Flaherty and Sethi's (2010) war-zone hypothesis, it is consistent with their finding that modern drug prohibitions lead to more lethal violence. 


\section{References}

Acemoglu, Daron, David H. Autor, and David Lyle. 2004. "Women, war, and wages: The effect of female labor supply on the wage structure at midcentury." Journal of Political Economy 112(3): 497- .

Adorno, Valentina. 2007. Program Evaluation with Continuous Treatment: Theoretical Considerations and Empirical Application. PhD. dissertation: Università di Bologna.

Association of Religion Data Archives. Statistics of Churches in the United States, County File, 1890. Available at

http://www.thearda.com/Archive/Files/Downloads/1890CENSCT DL2.asp.

Ayers, Edward L. 1984. Vengeance and Justice: Crime and Punishment in the $19^{\text {th }}$-Century American South. New York: Oxford University Press.

Blakely, Leonard Stott. 1912. The Sale of Liquor in the South: The History and Development of a Normal Social Restraint in Southern Commonwealths. Columbia University Studies in History, Economics and Public Law, Vol. 51. New York: Longmans, Green \& Co.

Boulding, Kenneth E. 1947. "A note on the theory of the black market." Canadian Journal of Economics and Political Science 13(1): 115-118.

Buseman, Michael J. 2002. One Trade, Two Worlds: Politics, Conflict, and the Illegal Liquor Trade in White County, Georgia and Pickens County, South Carolina, 1894-1895. MA thesis, University of Georgia.

Caulkins, Jonathan P., Peter Reuter, and Lowell Taylor. 2006. "Can supply restrictions lower price? Violence, drug dealing, and positional advantage." B.E. Journal of Economic Analysis \& Policy 5(1): 1-20.

Christensen, Niels, Jr. 1908. "The state dispensaries of South Carolina." Annals of the American Academy of Political and Social Sciences 32( ): 77-85.

Clary, Gary. 2016. South Carolina Circuit Court Judge (retired). Personal communication. 
Cook, Philip J. 2007. Paying the Tab: The Economics of Alcohol Policy. Princeton: Princeton University Press.

Copeland, Wilbur F. 1892. Handbook of Probibition Facts. New York: Funk \& Wagnalls Company.

Eubanks, John Evans. 1950. Ben Tillman's Baby: The Dispensary System of South Carolina, 1892-1915. Augusta, Georgia: Tidwell Printing Supply Company.

Flores, Daniel. 2016. "Violence and law enforcement in markets for illegal goods." International Review of Law and Economics 48: 77-87.

Glaeser, Edward L. and Bruce Sacerdote. 1999. "Why is there more crime in cities." Journal of Political Economy 107(S6): 225-258.

Hendricks, Ellen Alexander. 1945a. "The South Carolina dispensary system, part I." North Carolina Historical Review 22(2): 176-197.

Hendricks, Ellen Alexander. 1945b. "The South Carolina dispensary system, part II." North Carolina Historical Review 22(3): 320-349.

Jensen, Gary F. 2000. "Prohibition, alcohol, and murder: Untangling countervailing mechanisms." Homicide Studies 4(1): 18-36.

Knowles, John, Nicola Persico, and Petra Todd. 2001. "Racial bias in motor vehicle searches: theory and evidence.” Journal of Political Economy 109(1): 203-229.

Lechner, Michael. "The estimation of causal effects by difference-in-difference methods." Foundations and Trends in Econometrics 4(3): 165-224.

Levitt, Stephen D. and Sudhir Alladi Venkatesh. 2000. "An economic analysis of a drug-selling gang's finances." Quarterly Journal of Economics 115( ): 755-789.

Livingston, Brendan. 2016. "Murder and the black market: Prohibition's impact on homicide rates in American cities." International Review of Law and Economics 45(1): 33-44.

Miron, Jeffrey A. 1999. "Violence and the U.S. prohibition of drugs and alcohol." American Law and Economics Review 1(1): 78-114.

Miron, Jeffrey A. 2004. Drug W ar Crimes. Washington, DC: Independent Institute.

Miron, Jeffrey A. and Jeffrey Zweibel. 1995. "The economic case against drug prohibition." Journal of Economic Perspectives 9(4): 175-192. 
O'Flaherty, Brendan and Rajiv Sethi. 2010. "Peaceable kingdoms and war zones: Preemption, ballistics, and murder in Newark." In The Economics of Crime: Lessons for and from Latin America, 305-353. Edited by Rafael Di Tella, Sebastian Edwards, and Ernesto Schargrodsky. Chicago: University of Chicago Press.

Okrent, Daniel. 2010. Last Call: The Rise and Fall of Probibition. New York: Simon and Schuster.

Owens, Emily G. 2011. "Are underground markets really more violent? Evidence from early $20^{\text {th }}$ century America." American Law and Economics Review x(x): 144.

Owens, Emily G. 2014. "The American temperance movement and market-based violence." American Law and Economics Review x(x): 433-472.

Oxford English Dictionary Online. 2011. Accessed April 2016.

Sheen, Dan R. 1910. "Shall we compensate the liquor traffic?" American Prohibition Year Book 10: 129-132.

Smith, Helen Glenn. 2005. “The red tape cocktail: Charleston's reaction to the South Carolina dispensary system." Chrestomatby 4: 195-217.

South Carolina. Attorney General. 1888-1902. Report of the Attorney General to the General Assembly of South Carolina for the Fiscal Year. Columbia: The State Company, State Printers.

South Carolina. State Board of Control. 1897-1905. Report of the State Board of Control for the Fiscal Year. Columbia, SC: Bryan Printing Company.

South Carolina. Commissioner of Agriculture, Commerce and Industries. 1913. Twelfth Annual Report (1912). Columbia: Gonzales and Bryan, State Printer.

South Carolina. House of Representatives. 1899. "Governor's Message.” Journal of the House of Representatives of the General Assembly of the State of South Carolina. Columbia, SC: Bryan Printing Co., State Printers.

South Carolina. Senate and House of Representatives. "Memorial of the general assembly of the state of South Carolina to the Congress of the United States 
in the matter of receivers of railroad corporations and the equity jurisdiction of the courts in the United States." American Law Review 28(2): 161-195.

Szymanski, Ann-Marie E. 2003. Pathways to Probibition: Radicals, Moderates, and Social Movement Outcomes. Durham, NC: Duke University Press.

Timberlake, James H. 1966. Prohibition and the Progressive Movement, 1900-1920. Cambridge: Harvard University Press.

Torres-Reyna, Oscar. 2007. "Panel Data Analysis: Fixed and Random Effects using Stata (v.4.2). Available at https://www.princeton.edu/ otorres/Panel101.

Wainwright, Tom. 2016. Narconomics: How to Run a Drug Cartel. New York: Public Affairs.

Warburton, Clark. 1932. The Economic Results of Probibition. New York: Columbia University Press. 
Appendix A1

The figure presents a representative page of the South Carolina Attorney General Annual Reports. The figure is from Greenville County for the 1901 calendar year. The liquor law and murder prosecution and arrest data are derived from these sources. Thus, the state solicitor dismissed (nolled) 10 murder defendants, convicted 15 defendants, six of whom were sentenced to the penitentiary for a less than life term, six for a life term, and three were convicted of capital murder.

Report of the Sollcitor of the Eighth Clrcult of Cases Trled and Disposed of During the Year Ending the 1st Day of December, 1901.

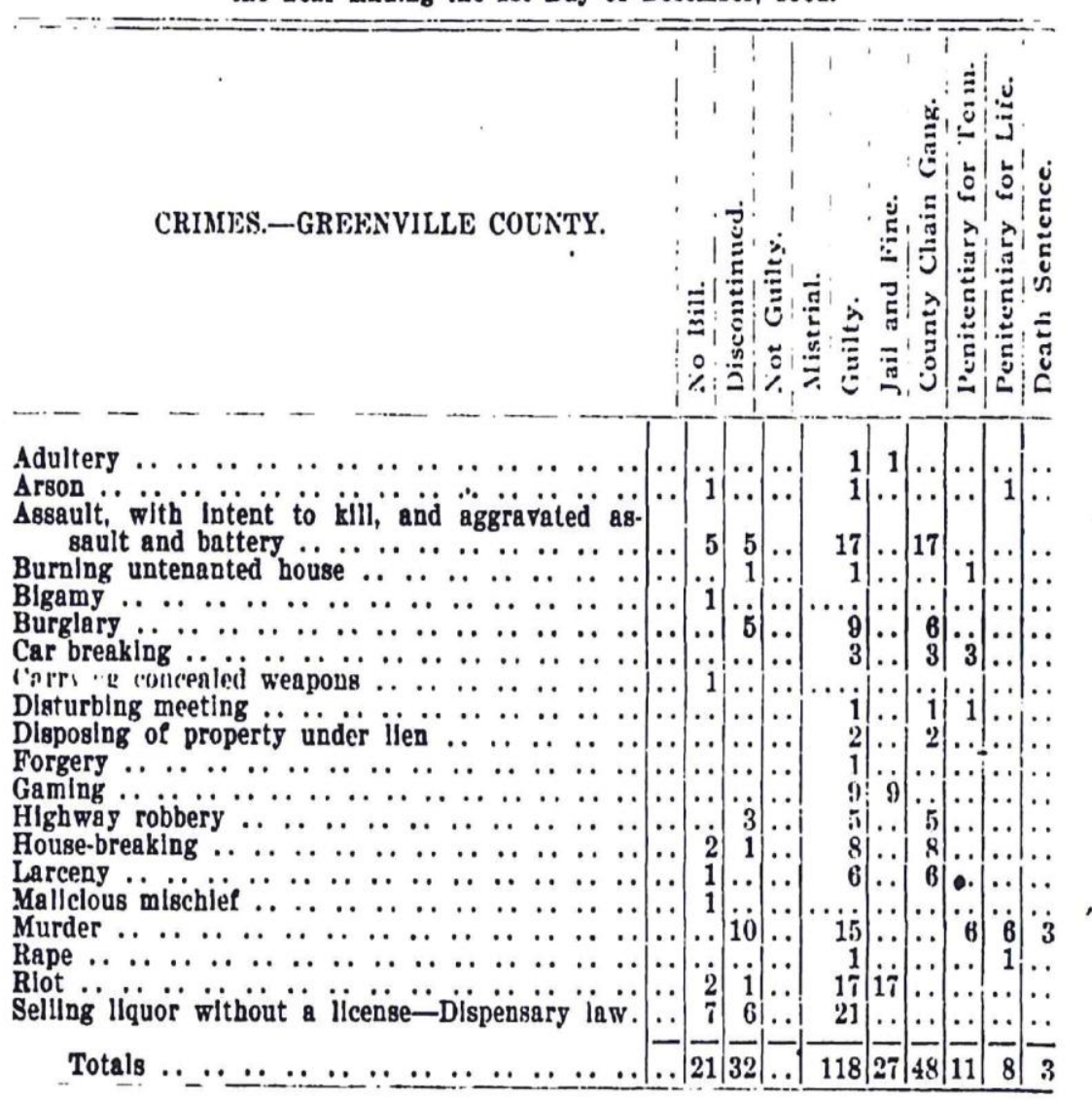

Source: South Carolina Attorney General (1902). 